\title{
KARAKTERISITIK FISIKOKIMIA MI BIHUN BERAS SUBSTITUSI PARSIAL TEPUNG RUMPUT LAUT Eucheuma cottoni
}

\author{
Hardoko $^{\text {a*, Anies Chamidah }}{ }^{\mathrm{a}}$, Mikchaell A.P. Panjaitan ${ }^{\mathrm{a}}$, Ain Nun Fakhurur Haryady ${ }^{\mathrm{a}}$ \\ aProdi Teknologi Hasil Perikanan, Fakultas Perikanan dan Ilmu Kelautan, Unversitas Brawijaya, Jl. Veteran \\ No. 1, Malang 65145, Indonesia \\ *Koresponden penulis (Alamat email): hardoko@ub.ac.id
}

\begin{abstract}
Abstrak
Mi bihun merupakan salah satu produk mi tradisionil Indonesia berbahan dasar tepung beras dan berkarakteristik mudah patah. Penelitian ini bertujauan untuk membuat bihun yang lebih kuat dan lebih berserat dengan melakukan subtitusi dengan rumput laut E. cottonii. Metode yang digunakan adalah metode eksperimen dalam bentuk perlakuan subtitusi E. cottonii sebesar $25 \%$, 30\%, dan 35\% b/b. Hasilnya menunjukkan bahwa subtitusi rumput laut $E$. cottonii dalam pembuatan mi bihun dapat menaikkan daya patah bihun, daya rehidrasi, dan warna bihun menjadi merah $\left({ }^{\circ} \mathrm{Hue} 42,35-44,53\right)$, tetapi kecerahan menurun. Bihun subtitusi yang paling disukai adalah bihun yang disubtitusi dengan E. cottonii $25 \%$ dengan nilai tingkat kesukaan 3,55 (suka) dari skala hedonik 1-5. Mi bihun subtitusi dengan E. cottonii terpilih memenuhi SNI 01-2975-2006, daya patah 3,03N (naik 11,4\%), daya serap air 128,42\% (naik 68,6\%), dan rendemen 54,80\%, serta mengandung serat pangan $6,26 \%$.
\end{abstract}

Kata kunci: E. cottonii, mi bihun, tepung, subtitusi

\begin{abstract}
Noodle vermicelli is one of Indonesia's traditional noodle products made from rice flour and the vermicelli is characterized by breaking easily. This research aimed to make the vermicelli stronger and more fibrous by substituting E. cottonii seaweed. The method used was an experimental method in the form of E. cottonii substitution treatment of $25 \%, 30 \%$, and $35 \% \mathrm{w} / \mathrm{w}$. The results show that the substitution of E. cottonii seaweed in the manufacture of vermicelli noodles can increase the power of vermicelli breaking, rehydration power, and the color of the vermicelli becomes red ( $\left.{ }^{\circ} \mathrm{Hue} 42,35-44,53\right)$, but the brightness decreases. The most preferred substituted vermicelli is substituted with $25 \%$ E. cottonii with a preference level of 3.55 (likes) from a hedonic scale of 1-5. The substituted vermicelli noodles with E. cottonii were selected to meet SNI 01-2975-2006, fracture strength 3.03N (increased 11.4\%), water absorption capacity $128.42 \%$ (increased $68.6 \%$ ), and yield $54.80 \%$, and contains $6.26 \%$ dietary fiber.
\end{abstract}

Keywords: E. cottonii, flour, substitute, vermicelli noodle.

\section{PENDAHULUAN}

Bihun adalah salah satu diversifikasi makanan berbentuk mi yang berbahan baku tepung beras. Pembuatan bihun yaitu tepung beras dimasak, dan dicetak menjadi bentuk seperti benang-benang, lalu dikeringkan. Bihun mengandung komposisi kimia yaitu antara lain kadar air sebesar $12,05 \%$, kadar abu $0,35 \%$, kadar protein $0,54 \%$, kadar lemak $1,17 \%$ dan kadar karbohidrat sebesar 85,91\% [1]. Ditinjau dari karakteristiknya, bihun mengandung amilosa tinggi namun kadar serat yang rendah, tekstur yang keras, dan mudah patah. Untuk menghasilkan bihun dengan kualitas baik diperlukan bahan baku dengan karakteristik pati tertentu. Pati yang ideal untuk bahan baku bihun adalah pati yang memiliki ukuran granula kecil, kandungan amilosa tinggi, derajat pembengkakan dan kelarutan terbatas serta karakteristik pasta tipe C (tidak memiliki puncak viskositas namun viskositas cenderung tinggi dan tidak mengalami penurunan selama proses pemanasan dan pengadukan) [2]. Selain itu, diperlukan pula campuran alternatif dengan bahan lain untuk mengurangi bahan baku utama beras. Misalnya, pembuatan bihun dengan menggunakan pati Aren [3], tepung sorghum termodifikasi [4], tepung singkong dan tepung kacang merah [5], tepung tulang ikan patin [6].

Kandungan karbohidrat dan karagenan yang cukup tinggi serta karakteristik pasta dari rumput laut $E$. cottonii berpotensi untuk bahan tambahan/substitusi dalam pembuatan bihun. Kandungan hidrokoloid dalam karagenan dapat 
memperbaiki tekstur dan karakteristik pasta dari adonan bahan baku bihun, dapat meningkatkan tekstur dari produk pangan ketika dikombinasikan dengan pati, dan dapat membantu meningkatkan kestabilan pasta pati terhadap panas berkelanjutan dan gaya gesekan. Selain itu, kandungan serat rumput laut dapat membuat mi lebih kenyal [7]. Dalam produk makanan, rumput laut sering digunakan sebagai alternatif bahan tambahan yang menguntungkan dan meningkatkan nilai gizi.

Karagenan dapat terekstraksi dengan air panas dan mempunyai kemampuan untuk membentuk gel. Sifat pembentukan gel pada rumput laut dibutuhkan untuk menghasilkan pasta yang baik, karena termasuk ke dalam golongan Rhodophyta yang menghasilkan florin starch. Karakteristik gel karagenan dicirikan oleh tipe gel yang lebih kuat dan memiliki efek sinergis yang tinggi dengan locust been gum. Karagenan juga dapat melakukan interaksi dengan makromolekul yang bermuatan seperti protein sehingga mempengaruhi peningkatan viskositas, pembentukan gel dan pengendapan [8]. Kekuatan gel karagenan berkisar 449,51559,51 dyne $/ \mathrm{cm}^{2}$ [9]. Serat pangan pada rumput laut jenis $E$. cottonii kering mencapai $65,07 \%$ yang terdiri dari $39,47 \%$ serat makanan tidak larut air dan $25,57 \%$ serat makanan larut air, sehingga jenis rumput laut ini termasuk dalam kelompok bahan berserat makanan tinggi [10].

Bihun berbahan baku beras biasanya bertekstur mudah patah dan kurang kenyal. Hal ini berbeda dengan karakteristik karagenan yang berserat dan kenyal. Penambahan rumput laut dapat mempengaruhi kualitas dan tekstur mi yang dihasilkan menjadi lebih baik [11]. Selain itu, Dengan adanya rumput laut pada campuran adonan mi basah dapat menambah kadar serat pada mi basah dan juga berpengaruh pada tekstur mi [12]. Penelitian [13] dan penelitian Susanti dan [14], mendapatkan bahwa karagenan dapat meningkatkan viskositas dan swelling power mi berbahan terigu. Berdasarkan karakteristik karagenan (dari E. cottonii) dapat memperbaiki mi terigu, maka ada kemungkinan juga dapat memperbaiki mi bihun ari tepung beras. Oleh sebab itu perlu dilakukan penelitian substitusi tepung E. cottonii pada produk bihun guna mengetahui pengaruhnya terhadap karakteristik mi bihun. Substitusi E. cottonii juga diharapkan dapat memperbaiki karakteristik bihun, mulai karakteristik fisik, kimia dan organoleptik produk bihun yang dihasilkan.

\section{METODE}

Metode yang digunakan dalam penelitian ini adalah metode eksperimental melalui perlakuan substitusi tepung $E$. cottonii terhadap bahan beras $25 \%, 30 \%$, dan $35 \%$. Formulasi percobaan pembuatan bihun subtitusi E. cottonii dapat dilihat pada Tabel 1.

Tabel 1. Formulasi mi bihun beras yang disubtitusi rumput laut E. cottonii.

\begin{tabular}{lccc}
\hline \multirow{3}{*}{ Bahan } & \multicolumn{3}{c}{ Perlakuan subtitusi } \\
\cline { 2 - 4 } & $\begin{array}{c}\mathbf{N}_{\mathbf{1}} \\
\mathbf{( 2 5 \% )}\end{array}$ & $\begin{array}{c}\mathbf{N}_{2} \\
\mathbf{( 3 0 \% )}\end{array}$ & $\begin{array}{c}\mathbf{N}_{3} \\
\mathbf{3 5 \%})\end{array}$ \\
\hline Tapioka & $28 \mathrm{~g}$ & $28 \mathrm{~g}$ & $28 \mathrm{~g}$ \\
Air & $70 \mathrm{~g}$ & $70 \mathrm{~g}$ & $70 \mathrm{~g}$ \\
STPP & $0,21 \mathrm{~g}$ & $0,21 \mathrm{~g}$ & $0,21 \mathrm{~g}$ \\
T. beras & $52,5 \mathrm{~g}$ & $49 \mathrm{~g}$ & $45,5 \mathrm{~g}$ \\
T. E. cottonii & $17,5 \mathrm{~g}$ & $21 \mathrm{~g}$ & $24,5 \mathrm{~g}$ \\
\hline
\end{tabular}

Sumber: Modifikasi [15]

\section{Prosedur Pembuatan Bihun}

Air direbus hingga mendidih dan substitusi tepung E. cottonii, kemudian ditambahkan campuran tepung beras dan tepung E. cottonii sesuai perlakuan. Selanjutnya dilakukan penambahan STPP sebanyak 0,21 g untuk proses gelatinisi. Penambahan STPP berfungsi untuk mempengaruhi kekenyalan pada bihun. Pati yang telah tergelatinisasi kemudian ditambahkan tepung tapioka sebanyak $28 \mathrm{~g}$. Pembuatan adonan dilakukan dengan cara menguleni sampai adonan tercampur rata dan kemudian dicetak dengan ukuran diameter lubang 2,5 $\mathrm{mm}$ dan membentuk untaian bihun. Untaian hasil pencetakan kemudian dikukus dalam panci pada suhu $\pm 100^{\circ} \mathrm{C}$ selama 30 menit. Setelah itu ditiriskan selama 10 menit hingga dingin. Kemudian bihun dioven 
menggunakan oven pada suhu $50^{\circ} \mathrm{C}$ selama \pm 18 jam sehingga diperoleh bihun kering.

\section{Parameter uji}

Parameter uji yang dilakukan pada bihun meliputi uji warna [16], daya patah (tensile strength) [17], rehidrasi [18], kadar air [19], kadar abu [20], kadar lemak [21], kadar protein [19], kadar karbohidrat by difference [22], kadar serat [23], dan organoleptik hedonik [24].

\section{HASIL DAN PEMBAHASAN}

\section{Rendemen Bihun}

Rendemen merupakan faktor yang menunjukkan seberapa banyak produk yang dihasilkan dari bahan mentah yang telah mengalami proses pengolahan. Semakin tinggi rendemen yang dihasilkan maka semakin rendah proses penyusutan yang terjadi selama pengolahan [25].

Hasil perhitungan rendemen pertahapan proses dan rendemen akhir proses pembuatan bihun yang disubtitusi rumput laut dapat dilihat pada Tabel 2.

Tabel 2. Rendemen tiap tahapan dan akhir proses pembuatan bihun-rumput laut.

\begin{tabular}{lc}
\hline Tahap & Rata-rata \pm SD $(\%)$ \\
\hline Pembuatan adonan & $99,53 \pm 0,32$ \\
Pencetakan & $99,03 \pm 0,13$ \\
Pengukusan & $104,98 \pm 0,12$ \\
Penirisan & $101,49 \pm 0,14$ \\
Pengovenan (Rendemen) & $54,80 \pm 0,45$ \\
\hline
\end{tabular}

Pada tahap pembuatan adonan dan pencetakan terjadi sedikit penurunan berat dan rendemennya tidak mencapai $100 \%$. Hal ini dikarenakan pada saat pencampuran bahan dan pencetakan, ada sebagian bahan campuran yang tertinggal dan terakumulasi pada wadah atau alat yang digunakan. Hal ini sejalan dengan pernyataan [26], bahwa sisa bahan yang tertinggal dalam wadah setiap tahap pada proses pembuatan akan mempengaruhi rendemen mi yang dihasilkan.
Tahap pengukusan menghasilkan rendemen sebesar 104,98\%. Nilai rendemen melebihi angka $100 \%$, terkait dengan adanya penyerapan air oleh adonan selama pengukusan sehingga kadar air meningkat dan berat bihun bertambah. Menurut [27], selama pengukusan berlangsung, uap panas datang dari arah bawah steam blancher, sehingga permukaan bihun bagian bawah menerima uap panas lebih awal dan lebih banyak. Uap panas tersebut juga mengakibatkan peningkatan kadar air pada bihun selama proses berlangsung. Selama pengukusan berlangsung proses gelatinisasi pati terjadi. Hal ini dapat dilihat dari perubahan warna untaian bihun menjadi lebih transparan.

Dalam tahap penirisan terjadi penurunan rendemen dibandingkan pada tahap pengukusan dan sedikit peningkatan rendemen dibanding tahap pencetakan. Penurunan rendemen dikarenakan pada saat proses penirisan terjadi pengurangan kadar air bihun, sedangkan peningkatan rendemen menunjukkan Sebagian air tertahan selama proses gelatinisasi pati dan rumput laut. Ttujuan dari penirisan adalah untuk mengurangi atau menghilangkan kandungan air pada permukaan bahan dan dilakukan sesegera mungkin setelah perlakuan [28].

Pengovenan merupakan tahap terakhir pembuatan bihun dan sekaligus menghasilkan rendemen produk yang mencapai $54,48 \%$. Pada tahap pengovenan terjadi pengurangan kadar air oleh suhu panas oven sehingga rendemen yang dihasilkan hanya setengah dari total, namun telah dapat mencapai kadar air yang relatif aman untuk penyimpanan produk. Bihun yang diperoleh dikemas menggunakan plastik Polyprophylene (PP) untuk melindunginya selama penyimpanan [29].

Rendemen bihun hasil subtitusi dengan rumput laut mencapai $54,80 \%$. Nilai ini lebih rendah jika dibandingkan dengan nilai rendemen mi instan yang disubtitusi dengan tepung mocaf dan tepung jagung [30] yang mencapai $68,89 \%$. Perbedaan hasil rendemen ini dapat disebabkan oleh perbedaan jenis dan sifat bahan utama dan bahan tambahan yang digunakan. Bihun menggunakan beras sebagai bahan baku utamanya sedangkan mi instan menggunakan tepung terigu sebagai bahan 
baku utama. Sebagaimana dikatakan oleh [27], mutu mi dan bihun sangat dipengaruhi oleh mutu bahan baku yang digunakan saat proses pembuatan dan jenis bahan tambahan yang digunakan. Menurut [31], setiap jenis hidrokoloid mempunyai kemampuan yang berbeda dalam menyerap dan menahan air selama gelatinisasi dan pengeringan.

\section{Daya Patah (Tensile Strength)}

Pengukuran kuat patah adalah pengukuran untuk memberi gambaran ketahanan bihun kering selama penanganan yang melibatkan perlakuan mekanis [32]. Hasil Anova menunjukkan bahwa subtitusi tepung rumput laut $E$. cotonii pada bihun berpengaruh nyata terhadap nilai daya patah bihun $(\mathrm{p}<0,05)$. Hasil uji lanjut dengan Duncan nilai daya patah bihun dapat dilihat pada Gambar 1.

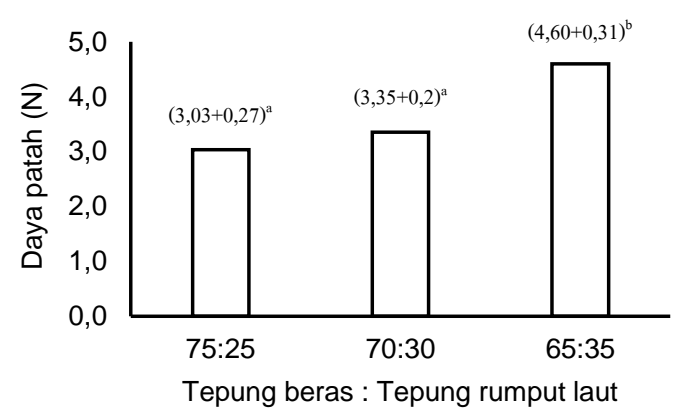

Keterangan : huruf superscript menunjukkan beda nyata $(\mathrm{p}<$ $0,05)$

Gambar 1. Substitusi tepung rumput laut E. cottoni terhadap daya patah bihun kering

Gambar 1 memperlihatkan peningkatan nilai daya patah seiring dengan peningkatan subtitusi tepung rumput laut $E$. cottonii pada produk bihun. Fenomena ini menunjukkan bahwa penambahan $E$. cottonii membuat bihun menjadi lebih tidak mudah patah atau lebih kokoh. Nilai daya patah bihun yang disubtitusi E cottonii yang diperoleh lebih rendah jika dibandingkan bihun dari bahan sagu yang disubtitusi dengan pati yang dimodifikasi dengan HMT (heat moisture treatment) [29] yang mencapai nilai daya patah $14,53 \mathrm{~N}$. Substitusi pati termodifikasi Heat Moisture Treatment (HMT) sebanyak 50\% dapat meningkatkan kekerasan bihun sagu. Kemampuan pati termodifikasi HMT dalam meningkatkan tekstur bihun kemungkinan terkait dengan kekuatan gel. Semakin tinggi kadar serat maka akan menghasilkan produk dengan tekstur yang lebih kokoh dan kuat. Akibatnya produk menjadi lebih keras dan daya patahnya meningkat [22].

Meningkatnya nilai daya patah pada bihun yang disubtitusi dengan E. cottonii diduga karena adanya interaksi antara pati dari beras dan hidrokoloid dari tepung rumput laut E. cottonii. Menurut [33] dan [22], bahwa interaksi pati dan hidrokoloid dalam bahan pangan bersifat unik dan menguntungkan karena dapat memodifikasi tekstur dan reologi dari bahan pangan tersebut. Semakin banyak tepung rumput laut yang ditambahkan maka tekstur mi menjadi kurang kenyal karena rumput laut memiliki sifat mudah mengikat air. Semakin tinggi kadar serat maka akan menghasilkan produk dengan tekstur yang lebih kokoh dan kuat, sehingga produk menjadi lebih keras dan daya patahnya meningkat.

Nilai daya patah bihun yang disubtitusi dengan rumput laut $E$. cottonii dibawah nilai daya patah bihun sagu [1] sebesar 5,59 N. Perbedaan nilai daya patah yang dihasilkan, diduga karena perbedaan bahan baku yang digunakan. Bihun beras memiliki karakteristik daya patah lebih kecil jika dibandingkan dengan daya patah bihun sagu. Hal ini sejalan dengan pernyataan [34], bahwa bihun beras memiliki tingkat kekerasan yang lebih besar dibandingkan dengan bihun sagu, sehingga bihun beras lebih mudah patah. Hal ini dimungkinkan oleh adanya kandungan protein pada tepung beras menyebabkan terbentuknya kompleks amilosa-protein yang dapat menyebabkan peningkatan kekerasan matriks produk yang dihasilkan.

\section{Warna Bihun}

Derajat Hue menunjukkan warna dari suatu produk. ${ }^{\circ} \mathrm{Hue}$ adalah penggabungan dari nilai $a^{*}$ dan $b^{*}$ (Hutching, 1996). Pembacaan nilai $a^{*}$ dan $b^{*}$ pada produk menggunakan bantuan alat yang disebut color reader [16]. Hasil perhitungan derajat Hue $\left({ }^{0} \mathrm{Hue}\right)$ dan nilai kecerahan (lightness) produk bihun dapat dilihat pada Tabel 3. 
Tabel 3. ${ }^{\circ}$ Hue (warna) dan lightness bihun subtitusi rumput laut E. cottonii

\begin{tabular}{ccc}
\hline $\begin{array}{c}\text { Subtitusi T. beras } \\
\text { : T. } \boldsymbol{E} \text { cottonii }\end{array}$ & ${ }^{\circ}$ Hue & Lightness \\
\hline $100 \%: 0 \%$ & 57,64 & $49,12 \pm 0.11$ \\
$75 \%: 25 \%$ & 42,35 & $31,37 \pm 0,15^{\mathrm{c}}$ \\
$70 \%: 30 \%$ & 43,43 & $30,48 \pm 0,17^{\mathrm{b}}$ \\
$65 \%: 35 \%$ & 44,53 & $29,67 \pm 0,17^{\mathrm{a}}$ \\
\hline Keterangan $:-$ notasi huruf superscript menunjukkan beda nyata
\end{tabular}

Keterangan : - notasi huruf superscript menunjukkan beda nyata $(\mathrm{p}<0.05)$

Nilai derajat Hue bihun yang disubtitusi E. cottonii berkisar antara 42,35-44,53 masuk pada warna merah (18-54) dan bihun yang tidak disubtitusi 57,64 (kuning kemerahan), sedangkan bihun dari tepung beras HMT 83, 14-88,03 masuk dalam warana kuning kemerahan (yellow red) (54-90) [35] dan bihun dari sagu yang disubtitusi dengan HMT kisaran nilai derajat Hue berada pada nilai 102,3104,05 [1] masuk pada warna kuning (90-126).

Perbedaan nilai derajat Hue merupakan akibat mutu dan kandungan komposisi bahan yang digunakan, baik bahan baku utama maupun bahan substitusi/bahan tambahan. [27] menyatakan bahwa mutu mi dan bihun sangat dipengaruhi oleh mutu bahan baku yang digunakan saat proses pembuatan. E. cottonii termasuk dalam golongan alga merah yang didominasi oleh pigmen merah, sehingga bihun yang dihasilkan juga berwarna merah. Hal ini sesuai dengan pernyataan [36] dan [37] bahwa warna penyusun dari rumput laut merah $E$. cottonii diantaranya pigmen karoten (warna keemasan), pigmen fikoeritrin (warna merah) dan pigmen klorofil.

Tabel 4 juga memperlihatkan kecerahan warna dari bihun menurun seiring dengan peningkatan subitusi $E$ cottonii. Hal ini menunjukkan kecerahan warna menurun seiring dengan intensitas warna merah oleh peningkatan konsentrasi $E$ cottoni. Interaksi antara tepung/campuran tepung dan hidrokoloid memberikan pengaruh terhadap nilai warna $L$ pada uji fisik warna. Hal ini juga berlaku pada bihun dari tepung sukun. [38] menyatakan bahwa terdapat interaksi antara tepung/campuran tepung, hidrokoloid dan $\mathrm{CaCl}_{2}$ memberikan pengaruh yang nyata terhadap intensitas warna merah, intensitas warna kuning dan intensitas kecerahan (Ligthtness/L) bihun sukun.

Nilai warna $L$ bihun pada hasil penelitian berkisar 30,44-49,12. Nilai tertinggi $(49,12)$ terdapat pada perlakuan 100:0, yang mana masih lebih rendah jika dibandingkan dengan hasil penelitian bihun beras tanpa subtitusi [35] yang mempunyai nilai $\mathrm{L}$ 54,48-62,95. Perbedaan dengan kontrol yang digunakan dalam penelitian ini adalah karena selain tepung beras juga digunakan tepung tapioka dan tepung $E$. cottonii yang dapat menurunkan nilai L (Tabel 1).

\section{Kadar Air Bihun}

Hasil Anova menunjukkan bahwa subtitusi tepung rumput laut $E$. cotonii pada bihun berpengaruh nyata terhadap nilai kadar air bihun $(p<0,05)$. Hasil uji lanjut dengan Duncan dan nilai kadar air dapat dilihat pada Gambar 2.

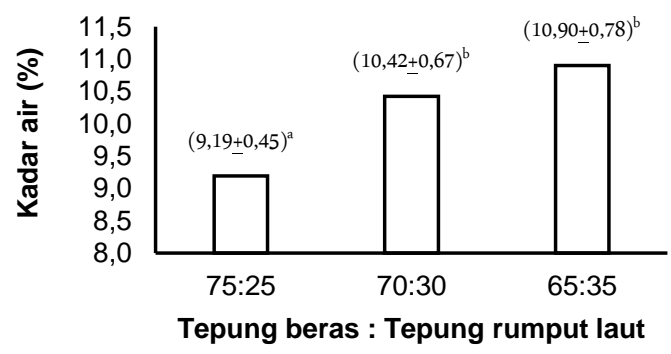

Keterangan : notasi huruf superscript menunjukkan beda nyata $(\mathrm{p}<0,05)$

Gambar 2. Substitusi tepung rumput laut $E$. cottoni terhadap kadar air bihun kering

Berdasarkan Gambar 2 diketahui bahwa nilai kadar air meningkat sejalan dengan bertambahnya tepung rumput laut $E$. cottoni yang disubtitusikan pada bihun. Hal ini mengindikasikan bahwa rumput laut $E$ cottonii meningkatkan daya ikat air pada bihun. Fenomena ini sesuai dengan [39] menyatakan bahwa rumput laut $E$. cottonii mempunyai sifat hidrokoloid yaitu kemampuan menyerap air yang tinggi.

Nilai kadar air bihun hasil subtitusi dengan E. cottonii lebih rendah jika dibandingkan dengan nilai kadar air bihun dasri tepung sagu yang disubtitusi dengan tepung HMT yang mencapai kadar air 12,05\% [1]. Perbedaan nilai kadar air diduga karena perbedaan komposisi bahan yang mempunyai sifat menahan air yang berbeda dan juga proses atau metode pengeringan yang digunakan. 
Meskipun demikian kadar air bihun tersebut sudah memenuhi persyaratan SNI 01-29752006 tentang produk bihun yang mensyaratkan kadar air maksimum 12\% [40].

\section{Rehidrasi Bihun}

Hasil Anova menunjukkan bahwa penambahan tepung rumput laut $E$. cotonii pada bihun berpengaruh nyata terhadap nilai rehidrasi bihun $(\mathrm{p}<0,05)$. Hasil uji lanjut dengan Duncan nilai rehidrasi dapat dilihat pada Gambar 3.

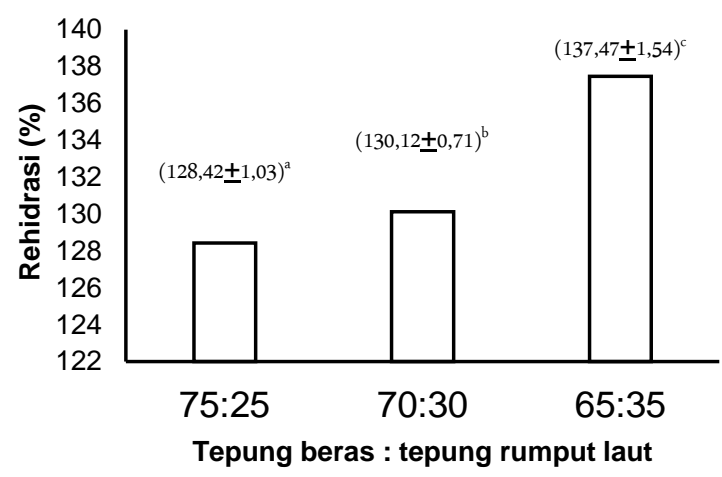

Keterangan : notasi huruf superscript menunjukkan beda nyata $(\mathrm{p}<0,05)$

Gambar 3. Substitusi tepung rumput laut $E$. cottoni terhadap nilai rehidrasi bihun kering

Berdasarkan gambar diatas diketahui bahwa semakin meningkatnya kadar tepung rumput laut $E$. cottoni yang ditambahkan, maka nilai rehidrasi bihun meningkat. Peningkatan nilai rehidrasi pada bihun terkait dengan tepung rumput laut E. cottoni termasuk kedalam senyawa hidrokoloid yang memiliki sifat pengikatan air dengan kapasitas yang besar. [41] menyatakan bahwa hidrokoloid seperti gum banyak digunakan dalam proses pembuatan mi instan karena bersifat sangat hidrofilik dan memiliki kapasitas pengikatan air yang besar.

Nilai rehidrasi bihun dari tepung beras yang disubtitusi rumput laut $\mathrm{E}$ cottonii lebih rendah jika dibandingkan dengan nilai rehidrasi bihun sagu yang dapat mencapai rehidrasi 264,79\% [29]. Perbedaan daya rehidrasi terkait dengan kandungan amilopektin yang tinggi pada pati sagu, sedangkan pada tepung beras me Penambahan bihun tepung beras yang disubtitusi rumput laut mengandung amilopektin lebih rendah. Hal ini didukung oleh [42] dan [43] yang menyatakan bahwa amilopektin mempunyai sifat rehidrasi yang baik pada produk pangan yang telah dikeringkan.

Bihun dengan persen rehidrasi tinggi cenderung mengalami pembengkakan baik selama pemasakan maupun pasca pemasakan. Pembengkakan akibat rehidrasi terkait dengan sifat tekstur mi, dimana makin tinggi sifat rehidrasi dapat menurunkan tekstur mi. Karakteristik bihun yang diharapkan adalah yang memiliki persen rehidrasi rendah, karena bihun dengan persen rehidrasi yang tinggi cenderung mengalami pembengkakan dan lebih mudah patah baik selama pemasakan maupun pasca pemasakan [38].

\section{Organoleptik Hedonik Bihun}

Produk pangan dibuat dan diolah tidak semata-mata untuk tujuan peningkatan nilai gizi, tetapi juga untuk mendapatkan karakteristik fungsional produk dan selera organoleptik konsumen. Karakteristik fungsional dan organoleptik itu diantaranya berhubungan dengan sifat tekstural produk pangan olahan seperti kerenyahan, kekekenyalan, dan penampakan, [44].

Organoleptik hedonik digunakan untuk mengukur tingkat kesukaan konsumen atau panelis terhadap suatu produk yang diungkapkan dalam skor atau skala kesukaan tertentu. Tingkat hedonik atau tingkat kesukaan terhadap suatu produk sangat penting untuk pemilihan produk. Meski parameter lain baik tetapi bila tingkat kesukaannya rendah, maka produk juga dianggap tidak baik [45]. Tingkat kesukaan terhadap bihun tepung beras yang disubtitusi dengan E. cottonii dapat dilihat pada Tabel 4 .

Tabel 4. Karakteristik organoleptik hedonik bihun hasil subtitusi E. cottonii.

\begin{tabular}{lcccc}
\hline Rasio & \multicolumn{4}{c}{ Atribut Hedonik } \\
\cline { 2 - 5 } TB:TE & Tekstur & warna & Rasa & Keseluruhan \\
\hline $75: 25$ & $3.40^{\mathrm{b}}$ & $3.30^{\mathrm{c}}$ & $3.55^{\mathrm{c}}$ & $3.55^{\mathrm{c}}$ \\
$70: 30$ & $2.75^{\mathrm{a}}$ & $3.15^{\mathrm{b}}$ & $3.20^{\mathrm{b}}$ & $3.04^{\mathrm{a}}$ \\
$65: 35$ & $2.65^{\mathrm{a}}$ & $2.95^{\mathrm{a}}$ & $3.10^{\mathrm{a}}$ & $3.35^{\mathrm{b}}$ \\
\hline Keterangan : TB = Tepung Beras; TE= Tepung E cottonii \\
Skor hedonik: 1= sangat tidak suka; 2= tidak suka; \\
3= netral; 4=suka; 5= sangat suka
\end{tabular}


Tekstur merupakan ciri suatu bahan sebagai akibat perpaduan dari beberapa sifat fisik yang meliputi antara lain ukuran, bentuk, jumlah dan unsur-unsur pembentukan bahan yang dapat dirasakan oleh indera peraba dan perasa, termasuk indera mulut dan penglihatan. Respon kesukaan terhadap tesktur bihun yang paling disukai adalah yang disubtitusi $E$. cottonii $25 \%$ dengan nilai respon kesukaan 3,4 (diatas netral) atau mulai agak suka.

Perbedaan konsentrasi tepung rumput laut E. cottoni yang ditambahkan mempengaruhi hasil tekstur produk bihun dan mempengaruhi tingkat kesukaan terhadap tekstur oleh panelis. Semakin tinggi konsentrasi rumput laut yang diberikan pada produk maka semakin tinggi pula nilai tekstur yang didapatkan oleh produk, dan sebaliknya [46]. Ditambahkan lagi oleh [47] bahwa sifat penting dari rumput laut adalah sifat fungsionalnya yang dapat mengontrol air, menstabilkan dan membentuk tekstur sesuai yang diinginkan. Interaksi sifat-sifat tersebut baru menghasilkan sifat organoleptik hedonik terhadap tekstur agak suka.

Menurut [22] secara visual faktor warna akan tampil terlebih dahulu dan sering kali menentukan nilai suatu produk. Peningkatan subtitusi E. cottonii pada bihun justru menurunkan tingkat kesukaan terhadap warna bihun. Hal ini terkait dengan warna merah dengan kecerahan yang menurun pada bihun (Tabel 3). Ini mengindikasikan panelis kurang menyukai produk bihun yang kurang cerah. Respon panelis yang berbeda terhadap nilai atribut warna bihun diduga karena perbedaan konsentrasi tepung rumput laut $E$. cottonii yang ditambahkan pada produk bihun. Semakin bertambahnya konsentrasi tepung rumput laut E. cottonii yang ditambahkan maka warna bihun akan semakin pekat dan mendekati warna coklat tepung rumput laut. Hal tersebut didukung oleh [48] menyatakan bahwa penambahan karagenan dalam produk menghasilkan gel yang berwarna agak gelap. Ditambahkan pula oleh [49], bahwa kombinasi perlakuan karagenan menghasilkan gel yang berwarna semakin gelap sesuai dengan peningkatan konsentrasi yang ditambahkan.

Rasa adalah sensasi yang diterima oleh indera perasa (lidah) saat mengkonsumsi makanan. Rasa merupakan tanggapan atas adanya rangsangan kimiawi yang sampai di indera pengecap lidah, khususnya jenis rasa dasar yaitu manis, asin, asam, pahit [50], dan enak atau tidak enak suatu produk [51]. Respon kesukaan panelis terhadap rasa bihun subtitusi rumput laut juga menurun seiring dengan penngkatan subtitusi dan paling tinggi hanya mencapai respon kesukaan diatas netral (>3.0) atau respon agak suka dengan nilai 3.55 yaitu pada subtitusi $25 \%$. Hal ini didukung [12] yang menyatakan bahwa penambahan tepung rumput laut sebanyak 10\% menghasilkan rasa mi basah yang enak dan tidak mengganggu pada rasa yang dihasilkan.

Secara keseluruhan panelis lebih menyukai bihun yang disubtitusi dengan $25 \%$ E. cottonii (Table 4) dan mencapai tingkat kesukaan 3.55 (suka). Respon kesukaan ini merupakan interaksi dari berbagai karaktersitik fisiko kimia bihun.

\section{Karaktersitik Bihun Terpilih}

Karena produk pangan dibuat dan diolah tidak semata-mata untuk tujuan peningkatan nilai gizi, tetapi juga untuk mendapatkan karakteristik fungsional produk dan selera organoleptik konsumen, maka pemilhan bihun terbaik didasarkan pada hasil organoleptiknya. Bihun yang paling disukai berdasarkan atribut tekstur, warna, rasa dan keseluruhan adalah bihun yang disubtitusi dengan E. cottonii $25 \%$. Karakteristik kimia dan gizi bihun terpilih disajikan pada Tabel 5.

Tabel 5. Hasil analisis kimia dan gizi bihun subtitusi E cotonii

\begin{tabular}{lcc}
\hline Komponen & Kadar $(\%)$ & SNI 01-2975-2006 \\
\hline Air & 10,17 & Maks. 12 \% \\
Protein & 5,39 & Min. 6 \\
Lemak & 0,28 & - \\
Abu & 1,70 & Maks 2 \\
Karbohidrat & 85,11 & - \\
Serat pangan & 6,26 & - \\
-Larut air & 1,97 & \\
-Tidak larut air & 4,29 & \\
\hline
\end{tabular}

Berdasarkan Table 5 dapat dikatakan bahwa bihun subtitusi dengan E. cottonii memenuhi syarat SNI. Selain itu, bihun subtitusi mengandung serat pangan lebih tinggi 
daripada bihun beras tanpa subtitusi yang hanya mengandung serat $5,08 \%$ [35].

\section{KESIMPULAN}

Mi bihun subtitusi terpilih adalah bihun yang disubtitusi dengan E. cottonii $25 \%$ dan berkarakteristik hedonik disukai panelis, memenuhi SNI 01-2975-2006, dan berserat pangan lebih tinggi.

Karakteristik mi bihun subtitusi terpilih adalah mempunyai warna merah $\left({ }^{\circ} \mathrm{Hue} 43,43\right.$ ) dengan kecerahan warna merah 31,37 , daya patah $3,03 \mathrm{~N}$, sifat rehidrasi $128,42 \%$, dan rendemen $54,80 \%$.

\section{UCAPAN TERIMA KASIH}

Ucapan terima kasih diberikan kepada Fakultas Perikanan dan Ilmu Kelautan yang telah memberikan dana penelitian dengan SK nomor 60 tahun 2020.

\section{DAFTAR PUSTAKA}

[1] G. S. Handy, "Produksi bihun dari Sagu (Metroxylon sp.) yang disubstitusi pati termodifikasi Heat Moisture Treatment pada skala 2,5 kilogram," Skripsi, Institut Pertanian Bogor. 2010.

[2] Y. P. Budi, dan Harijono, "Pengaruh penambahan karagenan terhadap karakteristik pasta tepung Uwi dan Sagu sebagai bahan baku pembuatan bihun," Jurnal Pangan dan Agroindustri, vol. 2, no. 1, hal. 113-120, 2014. https://jpa.ub.ac.id/index.php/ jpa/article/download/28/35.

[3] A. Rahim, " Pengaruh cara bihun terhadap sifat fisikokimia pada pembuatan instant starch noodle dari pati Aren." $J$. Agroland., vol. 15, no. 2, hal. 101 - 105, Juni 2008.

[4] K. Haryani, G. Salindri, Jansonchia, dan Suryanto, "Pembuatan bihun dari tepung sorgum termodifikasi menggunakan Lactobacillus bulgaricus." Jurnal rekayasa Mesin, vol. 14, no. 1, hal. 2734, 2019.
[5] N. A. Rahmawatiningrum, "Eksperimen pembuatan bihun dengan subtitusi tepung singkong (Manihot utilissima) dan tepung kacang merah (Vigna umbellata), Skripsi, Fakultas Teknik, Universitas Negeri Semarang, 2019.

[6] A. Nur, V. Besti, dan H.D. Anggraini, "Formulasi dan karakteristik bihun tinggi protein dan kalsium dengan penambahan tepung tulang ikan Patin (Pangasius hypopthalmus) untuk balita stunting." Jurnal MKMI, vol 14, no. 2, hal. 157-164, Juni 2018.

[7] M. Astawan, S. Koswara, dan F. Herdiani, "Pemanfaatan rumput laut (Eucheuma cottonii) untuk meningkatkan kadar Iodium dan serat pangan selai dan dodol." Jurnal Teknologi dan Industri Pangan, vol. 15 , no. 1, hal. 61-69, 2004.

[8] Wasilah, "Substitusi bubur rumput laut (Eucheuma cottonii) dan berbagai jenis tepung singkong untuk peningkatan kualitas nugget ayam," Skripsi, Fakultas Pertanian dan Peternakan, Universitas Muhammadiyah Malang, 2016.

[9] L. Ega, C.G.C. Lopulalan, dan F. Meiyasa, "Kajian mutu karagenan rumput laut Eucheuma cottonii berdasarkan sifat fisiko-kimia pada tingkat konsentrasi Kalium Hidroksida (KOH) yang berbeda," Jurnal Aplikasi Teknologi Pangan, vol. 5, no. 2, hal. 38-44, 2016. http://dx.doi.org/10.17728/jatp.169.

[10] S.R. Kasim, "Pengaruh perbedaan konsentrasi dan lama waktu pemberian rumput laut E. cottonii terhadap kadar lipid serum darah tikus," Skripsi, Fakultas Perikanan dan Ilmu Kelautan, Universitas Brawijaya, 2004.

[11] I. Kumalasari, "Perbedaan penambahan rumput laut Eucheuma cottonii pada mi basah terhadap kekuatan regangan (Tensile), kadar serat kasar (Crude Fiber), dan daya terima," Skripsi, Universitas Sebelas Maret, Solo, 2010. 
[12] W. N. Adha, S. Loekman, dan Sumarto, Pengaruh penambahan rumput laut (Eucheuma cottonii) terhadap mutu mi basah," Jurnal Online Mahasiswa Bidang Perikanan dan Ilmu Kelautan, vol. 3, no. 2, hal 1-13, 2016.

[13] M. Romadhoni, dan Harijono, "Karakteristik pasta tepung gembili, pati sagu dan karagenan serta potensinya sebagai bihun," Jurnal Pangan Dan Agroindustri, vol. 3, no. 1, hal. 53-60, 2015.

[14] Susanti dan Harijono, "Pengaruh karagenan terhadap karakteristik pasta tepung Garut dan kecambah kacang Gude sebagai bahan baku bihun," Jurnal Pangan dan Agroindustri, vol. 2, no. 4, hal. 50-57, 2014.

[15] R. Wulandari, "Karakteristik bihun campuran tepung beras dan tepung jagung," Skripsi, Universitas Jember, 2016.

[16] S. Yuwono, dan T. Susanto, "Pengujian Fisik Pangan, Diktat, Universitas Brawijaya, Malang, 1998.

[17] D.M. Riki, Patrick, Bakti, dan Siswo, "Modifikasi ubi kayu dengan proses fermentasi menggunakan starter Lactobalcillus casei untuk produk pangan, Jurnal Teknologi Kimia dan Industri, vol. 2, no. 4, hal. 137-145, 2013.

[18] E. Setiawati, "Variasi jumlah penambahan tepung tempe pada pembuatan bihun dari tepung umbi Talas," Skripsi, Universitas Jember, 2008

[19] Wellyalina, F. Azima, dan Aisman, "Pengaruh perbandingan tetelan merah tuna dan tepung maizena terhadap mutu nugget, Jurnal Aplikasi Teknologi Pangan, vol. 2, no. 1, hal. 9-17, 2013.

[20] S. Sudarmadji, Haryono, Suhardi, "Prosedur Analisa Untuk Bahan Makanan dan Pertanian," Penerbit Liberty, Yogyakarta, 1997.
[21] A.M. Legowo, Nurwantoro, dan Sutaryo, "Buku Ajar Analisis Pangan," Universitas Diponegoro, Semarang, 58 hal, 2007.

[22] F.G. Winarno, "Kimia Pangan dan Gizi," PT. Gramedia Pustaka Utama, Jakarta, 253 hal, 2004.

[23] D.S. Slamet, M. Muhilal, D. Fardiaz, dan Simamarta, "Pedoman Analisis Zat Gizi," WB Saunders Company, Jakarta, 137 hal, 1990.

[24] D. Setyaningsih, "Analisis Sensori untuk Industri Pangan dan Agro," IPB Press, Bogor, 180 hal., 2010.

[25] E. Kartika, "Pembuatan mi kering dengan penambahan tepung daging sapi," Skripsi, Fakultas Peternakan, Institut Pertanian Bogor, 2010.

[26] N.Indrianti, E. Sholichah, dan D. A. Darmajana, "Proses pembuatan mi jagung dengan bahan baku tepung jagung 60 Mesh dan teknik SheetingSlitting," Jurnal Pangan, vol. 23, no. 3, hal. 256-267, 2014.

[27] A. F. Ramdhani, Harijono, dan Ella, "Pengaruh penambahan karagenan terhadap karakteristik pasta tepung garut dan kecambah kacang Tunggak sebagai bahan baku bihun, Jurnal Pangan dan Agroindustri. Vol. 2, no. 4, hal. 41-49, 2014.

[28] Y. N. Ningsih, "Modul Saintifikasi Jamu: Penanganan Pasca Panen," Fakultas Farmasi, Universitas Jember, 33 hal., 2016.

[29] D. Herawati, "Modifikasi pati sagu dengan teknik Heat Moisture-Treatment (HMT) dan aplikasinya dalam memperbaiki kualitas bihun," Tesis, Institut Pertanian Bogor, 2009.

[30] A.I. Wahdini, B. Susilo, dan R. Yulianingsih, "Uji karakteristik mi instan berbahan dasar tepung terigu dengan substitusi mocaf dan pati Jagung," Jurnal Keteknikan Pertanian Tropis dan 
Biosistem, vol. 2, no. 3, hal. 234-245, 2014.

[31] T. W. Widyaningsih, dan E. S. Murtini, "Alternatif pengganti formalin pada produk pangan, Trubus, Surabaya, 64 hal., 2006.

[32] C. L. Suryani, dan Haryadi, "Pemutihan dan pengikatan silang pati sagu dan penggunaannya untuk bahan substitusi pada pembuatan bihun," Agritech, vol. 18, no. 4, hal. 20-23, 1998.

[33] V. Sudhakar, R.S. Singhal, dan P.R. Kulkarni, "Effect of salts on interactions of starch with guar gums," Food Hydrocolloids, vol. 10, no, 3, hal. 329334, 1996.

[34] J. M. Martin, L. E. Talbert, D. K. Habernicht, S. P. Lanning, J. D. Sherman, G Carlson, dan M. J. Giroux, "Reduced amylose effects on bread and white salted noodle quality," Cereal Chemistry, vol. 81, no. 2, hal. 188-193, 2005. DOI: 10.1094/CCHEM.2004.81.2.188

[35] S. Widowati, H. Herawati., E. S. Mulyani, F. Yuliwardi, dan T. Muhandri, "Pengaruh perlakuan Heat Moisture Treatment (HMT) terhadap sifat fisiko kimia dan fungsional tepung beras dan aplikasinya dalam pembuatan bihun berindeks glikemik rendah," Jurnal Pascapanen, vol. 11, no. 2, hal. 59-66, 2014.

[36] M. T. Dolorosa, Nurjanah, S. Purwaningsih, E. Anwar, dan T. Hidayat, "Kandungan senyawa bioaktif bubur rumput laut Sargassum plagyophyllum dan Eucheuma cottonii sebagai bahan baku krim pencerah kulit." Jurnal Pengolahan Hasil Perikanan Indonesia, vol. 20, no. 3, hal. 633-644, 2017. DOI:10.1088/17551315/278/1/012020.

[37] A. B Ikrom, dan Aunurohim, "Kandungan klorofil-a dan karagenan Eucheuma cottonii yang ditanam pada kedalaman berbeda di desa Palasa, Pulau Poteran," Jurnal Teknik Pomits, vol. 2, no. 1, hal. 16, 2013.
[38] S. Agustin, "Kajian pengaruh hidrokoloid dan $\mathrm{CaCl}_{2}$ terhadap profil gelatinisasi bahan baku serta aplikasinya pada bihun sukun," Tesis, Institut Pertanian Bogor, 2011.

[39] D. Puspitasari, "Kajian substitusi tapioka dengan rumput laut (Eucheuma cottonii) pada pembuatan bakso," Skripsi, Fakultas Pertanian, Universitas Sebelas Maret, Surakarta, 2008.

[40] BSN, “SNI 01-2975-2006 : Bihun,” BSN, 2006.

[41] B.X. Fu, "Asian noodles: history, classification, raw materials and processing. Food Research Intl., vol. 41, no. 9, hal. 888-902, 2008. https://doi.org/10.1016/j.foodres.2007.11. 007.

[42] O.R. Fenema, "Food Chemistry 3th Eda. Marcel Dekker Inc, Newyork, 1996.

[43] H.D. Belitz, W. Grosch, P. Schieberle, "Food Chemistry $4^{\text {th }}$ revised and extended Eds.," Springer-Verlag Berlin Heidelberg, 2009.

[44] D. N. Midayanto, dan S. S. Yuwono, "Penentuan atribut mutu tekstur tahu untuk direkomendasikan sebagai syarat tambahan dalam Standar Nasional Indonesia." Jurnal Pangan dan Agroindustri, vol. 2, no. 4, hal. 259-267, 2014.

[45] S. Lestari, dan P. N. Susilawati, "Uji organoleptik mi basah berbahan dasar tepung talas Beneng (Xantoshoma undipes) untuk meningkatkan nilai tambah bahan pangaan lokal Banten.” Prosiding Seminar Nasional Masyarakat Biodiversitas Indonesia, vol. 1, no. 4, hal, 941-946, 2015.

DOI: 10.13057/psnmbi/m010451

[46] S. Wijana, A. F. Mulyadi' dan T. D. T. Septivirta, "Pembuatan permen jelly dari buah nanas (Ananas comosus L), Subgrade: Kajian Konsentrasi Karagenan dan Gelatin," Skripsi, Fakultas Teknologi 
Pertanian, Universitas Brawijaya, Malang, 2014.

[47] T. Estiasih, "Teknologi dan Aplikasi Polisakarida dalam Pengolahan Pangan," Fakultas Teknologi Pertanian, Universitas Brawijaya, 118 hal, 2006.

[48] D. Fardiaz, "Hidrokoloid," Pusat Antar Universitas Pangan dan Gizi, Institut Pertanian Bogor, 175 hal, 1989.

[49] I. R. Putri, Basito, dan E. Widowati, "Pengaruh konsentrasi Agar-Agar dan karagenan terhadap karakteristik fisik, kimia, dan sensori selai lembaran pisang Raja (Musa paradisiaca L.) varietas Raja Bulu," Jurnal Teknosains Pangan, vol. 2, no. 3, hal. 112-120, 2013.
[50] M.C. Meilgaard, G.V. Civille, and B.T. Carr, "Sensory Evaluation Techniques, $4^{\text {th }}$ Edition," CRC Press, Boca Raton, USA, 464 p, 2007.

[51] J. K. Negara, A. K. Sio, Rifkhan, M. Arifin, A. Y. Oktaviana, R. R. S. Wihansah, dan M. Yusuf, "Aspek mikrobiologis serta sensori (Rasa, Warna, Tekstur, Aroma) pada dua bentuk penyajian keju yang berbeda," Jurnal Ilmu Produksi dan Teknologi Hasil Peternakan, vol. 4, no. 2, hal. 286-290, 2016.https://doi.org/10.29244/jipthp.4.2. 286-290 